\title{
The Most Important Ethical Concerns in Science
}

\section{Kuo-Chen Chou}

Gordon Life Science Institute, Boston, Massachusetts 02478, United States of America

Correspondence to: Kuo-Chen Chou, kcchou@gordonlifescience.org, kcchou38@gmail.com

Keywords: High Similarity, Coercion, Falsify Data, Steal Ideas

Received: February 19, $2020 \quad$ Accepted: February 22, $2020 \quad$ Published: February 25, 2020

Copyright $\odot 2020$ by author(s) and Scientific Research Publishing Inc.

This work is licensed under the Creative Commons Attribution International License (CC BY 4.0).

http://creativecommons.org/licenses/by/4.0/

(c) (i) Open Access

\section{ABSTRACT}

The most unethical behaviors in science are of falsifying data and stealing ideas from previous investigators. But for publishing papers with high similarity and editing papers with coercion, it is necessary to carry out a concrete analysis case by case.

\section{INTRODUCTION}

The ethics in science are usually classified as: 1) publishing papers with high similarity; 2) falsifying data; 3 ) stealing ideas from previous investigators; 4) editing papers with coercion.

\section{DISCUSSION}

The problems by using the similarity software to evaluate the quality of scientific papers are as follows. 1) For the classic laws, theorems [1, 2], and rules [3], it is not allowed to change even one word. 2) In contrast, by using different words with essentially the same contents or ideas as the classic ones, so as to claim new findings or discovery. Unfortunately, the similarity software is unable to detect this kind of cheating behaviors. 3) In many music tunes composed by Bach Johann Sebastian and Wolfgang Amadeus Mozart (two of the most productive and influential composers for all time), their similarities are extremely high, but their tunes have been highly appreciated until now and even forever. Therefore, the practice of using the computer program to examine the quality of scientific papers must be rescinded or voided.

"Falsifying data" is a typical cheating, and so is "Stealing ideas from previous investigators". However, for the case of editing papers with coercion, the editor should be highly admired if he or she has found that some authors, by using different words with essentially the same contents or ideas to steal the credit from the previous investigators.

\section{CONCLUSION}

It is unethical in science to falsify data and steal ideas from previous investigators. But for publishing papers with high similarity and editing papers with coercion, it is necessary to carry out an analysis case by case. 


\section{CONFLICTS OF INTEREST}

The author declares no conflicts of interest regarding the publication of this paper.

\section{REFERENCES}

1. Chou, K.C. (1995) A Novel Approach to Predicting Protein Structural Classes in a (20-1)-D Amino Acid Composition Space. Proteins: Structure, Function \& Genetics, 21, 319-344. https://doi.org/10.1002/prot.340210406

2. Chou, K.C. and Zhang, C.T. (1995) Review: Prediction of Protein Structural Classes. Critical Reviews in Biochemistry and Molecular Biology, 30, 275-349. https://doi.org/10.3109/10409239509083488

3. Chou, K.C. (2011) Some Remarks on Protein Attribute Prediction and Pseudo Amino Acid Composition (50th Anniversary Year Review, 5-Steps Rule). Journal of Theoretical Biology, 273, 236-247.

https://doi.org/10.1016/j.jtbi.2010.12.024 